\title{
Radioactive Holmium Acetylacetonate Microspheres for Interstitial Microbrachytherapy: An In Vitro and In Vivo Stability Study
}

Wouter Bult • Hendrik de Leeuw • Olav M. Steinebach • Martijn J. van der Bom• Hubert Th. Wolterbeek • Ron M. A. Heeren • Chris J. G. Bakker • Alfred D. van het Schip •Wim E. Hennink •J. Frank W. Nijsen

Received: 23 May 2011 / Accepted: 17 October 2011 / Published online: 9 November 2011

(C) The Author(s) 2011. This article is published with open access at Springerlink.com

\begin{abstract}
Purpose The clinical application of holmium acetylacetonate microspheres (HoAcAcMS) for the intratumoral radionuclide treatment of solid malignancies requires a thorough understanding of their stability. Therefore, an in vitro and an in vivo stability study with HoAcAcMS was conducted.

Methods HoAcAcMS, before and after neutron irradiation, were incubated in a phosphate buffer at $37^{\circ} \mathrm{C}$ for 6 months. The in vitro release of holmium in this buffer after 6 months was $0.5 \%$. Elemental analysis, scanning electron microscopy, infrared spectroscopy and time of flight secondary ion mass spectrometry were performed on the HoAcAcMS.

Results After 4 days in buffer the acetylacetonate ligands were replaced by phosphate, without altering the particle size and surface morphology. HoAcAcMS before and after neutron irradiation were administered intratumorally in VX2 tumorbearing rabbits. No holmium was detected in the faeces, urine, femur and blood. Histological examination of the tumor revealed clusters of intact microspheres amidst necrotic tissue after 30 days.
\end{abstract}

Conclusion HoAcAcMS are stable both in vitro and in vivo and are suitable for intratumoral radionuclide treatment.
KEY WORDS brachytherapy · holmium · in vivo .

microspheres $\cdot \mathrm{V} X 2$ carcinoma

\section{INTRODUCTION}

Worldwide, cancer is the second cause of death, after cardiovascular diseases (1), and it is estimated that each year over 20 million new cases are presented (2). The majority (over 90\%) of these new cases are solid tumors, and each year over 12 million people die from solid tumors $(1,2)$. Traditionally, surgery has been the preferred treatment of solid malignancies, since this treatment can be considered curative (3), but, unfortunately, not all tumors are eligible for curative resection. In the 1990s minimally invasive treatment options were proposed as treatment of inoperable solid malignancies, to offer a potentially curative treatment and to reduce the morbidity associated with surgery. These minimally invasive treatments, which are increasingly applied nowadays, include radiofrequency ablation (4), high intensity focused ultrasound (5) and local administration of radionuclides $(6,7)$. With respect to the
W. Bult • A. D. van het Schip • J. F. W. Nijsen ( $\square)$

Department of Radiology and Nuclear Medicine, UMC Utrecht

Utrecht, The Netherlands

e-mail: f.nijsen@umcutrecht.nl

H. de Leeuw · M. J. van der Bom • C. J. G. Bakker

Image Sciences Institute, UMC Utrecht

Utrecht, The Netherlands

O. M. Steinebach $\cdot$ H. T. Wolterbeek

Department of Radiation, Radionuclides and Reactors

Section Radiation \& Isotopes for Health, Delft University of Technology

Delft, The Netherlands
R. M. A. Heeren

FOM institute for Atomic and Molecular Physics

Amsterdam, The Netherlands

W. E. Hennink

Department of Pharmaceutics

Utrecht Institute for Pharmaceutical Sciences

Utrecht University

Utrecht, The Netherlands 
latter category, the most widely used technique is radioembolization of liver malignancies using radioactive microspheres $(8,9)$. This technique involves the administration of yttrium-90 $\left({ }^{90} \mathrm{Y}\right)$ microspheres using a catheter placed in the hepatic artery. Another approach is the direct intratumoral injection of radiolabeled particles or substances. Intratumorally administered ${ }^{90} \mathrm{Y}$ glass microspheres have been successfully tested in humans (6). The results were promising: $90.6 \%$ of the tumors treated showed a size reduction, and apparent complete tumor necrosis was observed in 8 patients. Although these results were very promising, the extrahepatic delivery of microspheres, especially to the lungs, and the lack of accurate dose estimations were posed as problems to be overcome. Also, intratumoral administration of holmium-166 ( $\left.{ }^{166} \mathrm{Ho}\right)$ chelated to chitosan, an in situ gel forming device, has been tested in hepatocellular carcinoma patients with small $(\leq 3 \mathrm{~cm})$ solitary lesions (10). Complete tumor necrosis was observed in 31 of 40 patients, yet the release of holmium from the injection site led to haematologic side effects in 11 of 40 patients. In itself, ${ }^{166} \mathrm{Ho}$ is an ideal isotope since, in contrast to ${ }^{90} \mathrm{Y}$, it combines the emission of therapeutic beta particles with gamma rays. The gamma rays can be accurately visualized using gamma scintigraphy, which can be used for accurate dosimetric calculations. Moreover, holmium is a paramagnetic and electron dense element, allowing for magnetic resonance imaging and x-ray computed tomography (CT), respectively (11). Chitosan as a delivery device for ${ }^{166} \mathrm{Ho}$ however is not ideal due to leakage of ${ }^{166} \mathrm{Ho}$ from the complex, causing haematologic side effects. To further optimize the intratumoral application of ${ }^{166} \mathrm{Ho}$, holmium microspheres with an ultra high holmium load were proposed as a radioablation device for solid malignancies (12). These microspheres were suitable to deliver sufficient radiation after intratumoral administration, and their efficacy was tested in a renal cell carcinoma tumorbearing mouse model (13). The microsphere treated tumors did not show a significant growth $\left(141 \pm 99 \mathrm{~mm}^{3}\right.$ at time of treatment versus $104 \pm 95 \mathrm{~mm}^{3}$ after 2 weeks), whereas the tumor size in the saline treated control group increased dramatically (from $122 \pm 33 \mathrm{~mm}^{3}$ to $4,150 \pm 300 \mathrm{~mm}^{3}$ 2 weeks post-injection). In addition to the laboratory animal study, a pilot experiment was performed to assess the feasibility and tolerability of intratumoral administration of ${ }^{166}$ HoAcAcMS in feline liver cancer patients (14). The treatment was well tolerated, and the clinical condition of the cats improved. It was concluded that intratumoral administration of ${ }^{166} \mathrm{HoAcAcMS}$ is efficacious, and not associated with adverse effects.

The purpose of the present study was to investigate the long-term in vitro stability of these radioactive holmium acetylacetonate microspheres $\left({ }^{166} \mathrm{HoAcAcMS}\right)$. The holmium release from the HoAcAcMS was measured and the surface morphology and the chemical composition of the HoAcAcMS were investigated upon incubation of both non-neutron activated and neutron activated radioactive HoAcAcMS in phosphate buffer at $37^{\circ} \mathrm{C}$ for up to 26 weeks. The in vivo stability was assessed in VX-2 tumor-bearing rabbits, after intratumoral administration of both non-activated HoAcAcMS and neutron-activated HoAcAcMS. The rabbits were followed for 1 month, during which blood, urine and faeces were collected to determine the excretion of holmium. Histology was performed on tumor tissue, and the holmium content in the femur was determined.

\section{MATERIALS AND METHODS}

\section{Materials}

All chemicals were commercially available and used as received. Acetylacetone (2,4-pentanedione (AcAc; >99\%)), ammonium hydroxide $\left(\mathrm{NH}_{4} \mathrm{OH} ; 29.3 \%\right.$ in water), chloroform $\left(\mathrm{CHCl}_{3} ; \mathrm{HPLC}\right.$-grade), holmium phosphate (anhydrous $\left(\mathrm{HoPO}_{4} ;>99.99+\%\right.$ ), poly(vinyl alcohol) (PVA; average MW 30,000-70,000, 88\% hydrolyzed) and poloxamer 188 (Pluronic ${ }^{\circledR}$ F68, average MW 8350) were purchased from Sigma Aldrich (Steinheim, Germany). Di-sodium hydrogen phosphate dihydrate $\left(\mathrm{Na}_{2} \mathrm{HPO}_{4} \cdot 2 \mathrm{H}_{2} \mathrm{O} ; 99 \%\right)$, ethanol (absolute), holmium CertiPUR ICP Standard (1.00 $\mathrm{g} \mathrm{L}^{-1}$ ), sodium azide $\left(\mathrm{NaN}_{3} ; 99 \%\right)$ and sodium dihydrogen phosphate dihydrate $\left(\mathrm{NaH}_{2} \mathrm{PO}_{4} \cdot 2 \mathrm{H}_{2} \mathrm{O} ; 99 \%\right)$ were purchased from Merck (Darmstadt, Germany). Holmium chloride hexahydrate $\left(\mathrm{HoCl}_{3} \cdot 6 \mathrm{H}_{2} \mathrm{O}\right)$ was obtained from Metall rare earth (Shenzhen, China). Dexmedetomedine (Dexdomitor) and carprofen (Rimadyl) were obtained from Pfizer Animal Health B.V. (Capelle a/d IJssel, The Netherlands) and Isoflurane (IsoFlo) was obtained from Abbott Animal Health (Hoofddorp, The Netherlands).

\section{Preparation and Neutron Irradiation of HoAcAcMS}

HoAcAcMS with a size of $15 \mu \mathrm{m}$ were prepared by a solvent evaporation process previously described (12). The HoAcAcMS (300 or $600 \mathrm{mg}$ ) were weighed in high density polyethylene vials (Type A, Posthumus plastics, Beverwijk, the Netherlands). Neutron irradiations were performed in the pneumatic rabbit system operational at the research reactor facility of the Reactor Institute Delft (Delft University of Technology, The Netherlands) (15). Samples were irradiated for either $3 \mathrm{~h}$ or $6 \mathrm{~h}$ with a thermal neutron flux of $5 \times 10^{12} \mathrm{n} \mathrm{cm}^{-2} \mathrm{~s}^{-1}$, and the radioactive ${ }^{166}$ Ho was left to decay for 1 month in closed vials. 


\section{In Vitro Degradation of the Microspheres}

The release of $\mathrm{Ho}^{3+}$-ions from HoAcAcMS was determined as described by Zielhuis et al. (16). Neutron irradiated microsphere samples $(50 \mathrm{mg}$ ) were suspended in $100 \mu \mathrm{l}$ of $2 \%$ Pluronic ${ }^{\circledR}$ F68 aqueous solution and incubated in test tubes containing $5 \mathrm{~mL}$ isotonic phosphate buffer (116 mM, $39 \mathrm{mmol}$ of $\mathrm{NaH}_{2} \mathrm{PO}_{4} \cdot 2 \mathrm{H}_{2} \mathrm{O}$ and $77 \mathrm{mmol}$ of $\mathrm{Na}_{2} \mathrm{HPO}_{4} \cdot 2 \mathrm{H}_{2} \mathrm{O}$ in $1 \mathrm{~L}, \mathrm{pH} 7.4$ ) with $0.05 \% \mathrm{NaN}_{3}$ to prevent bacterial growth. All samples were prepared in duplicate. The tubes were placed in a water bath at $37^{\circ} \mathrm{C}$ and continuously shaken and at predetermined time points (1 day, 4 days, 1, 2, 4, 8, 12 and 24 weeks) the test tubes were centrifuged, and the supernatant was collected. The microspheres were washed three times with water for injection and dried at $50^{\circ} \mathrm{C}$. The microspheres and the supernatant were used for further analysis.

\section{Particle Surface Morphology}

Surface morphology of the HoAcAcMS after incubation was studied using a Phenom (Phenom World BV, Eindhoven, The Netherlands) scanning electron microscope. The samples were placed on aluminium stubs and sputter coated with a $6 \mathrm{~nm}$ Pt layer, and images were acquired at a voltage of $5 \mathrm{kV}$.

\section{Elemental Analysis}

The holmium, carbon, oxygen, hydrogen and phosphorous content was determined before and after incubation of HoAcAcMS in phosphate buffer by H. Kolbe (Mulheim an der Ruhr, Germany).

\section{Infrared Spectroscopy}

Fourier Transform Infrared spectroscopy was used to ascertain the presence of acetylacetonate in the microspheres. Infrared spectra of dried microspheres were acquired on a BIO-RAD FTS6000 FT-IR (BIO-RAD, Cambridge, MA, USA). The spectra were recorded from 400 to 4,000 $\mathrm{cm}^{-1}$ using $\mathrm{KBr}$ pellets, by accumulating 256 scans per spectrum.

\section{Secondary Ion Mass Spectrometry}

Time of flight secondary ion mass spectrometry (TOFSIMS) analysis was performed to obtain mass spectral information about the molecular composition and distribution on the surface of the microspheres before and after incubation in buffer (17). Samples were fixed on a conductive carbon sticker on a stainless steel sample holder, and measured using a TRIFT II mass spectrometer
(Physical Electronics, Eden Prairie, MN) equipped with a $\mathrm{Au}$ primary ion gun. $22 \mathrm{keV} \mathrm{Au}{ }^{+}$primary ions were used for analysis. SIMS spectra were measured both in the positive and the negative secondary ion mode with a secondary ion energy of $7 \mathrm{keV}$.

\section{In Vivo Degradation Study}

\section{Animal Model}

All experimental protocols and procedures were approved by the local experimental animal welfare committee and conform to national and European regulations for animal experimentation. Eight adult female New Zealand White rabbits of approximately $3.5 \mathrm{~kg}$ were purchased from Harlan (Horst, The Netherlands). The animals were housed individually to allow for urine and faeces collection and were fed approximately $100 \mathrm{~g}$ complete diet pellets for rabbits daily. Water was supplied ad libitum.

\section{Tumor Cells}

The VX2 cell line was a kind gift from dr. R.J.J. van Es (department of Oral and Maxillofacial surgery, University Medical Centre Utrecht, Utrecht, The Netherlands) (18). The VX2 cells were propagated by subcutaneous passage in the rabbit hind limb. After dissecting the tumor, small portions of viable tumor (2 $\mathrm{mm}$ in diameter) were selected for intrahepatic implantation as described by Nijsen et al. (19).

\section{Analgesia, Sedation and Euthanasia}

Analgesia during and 2 days post laparotomy was achieved with carprofen s.c. $4 \mathrm{mg} \mathrm{kg}^{-1}$ bodyweight. General anaesthesia was induced by ketamine i.m. at $30 \mathrm{mg} \mathrm{kg}^{-1}$ bodyweight and xylazine i.m. at $4 \mathrm{mg} \mathrm{kg}^{-1}$ bodyweight. Anaesthesia was maintained by inhalation of isoflurane

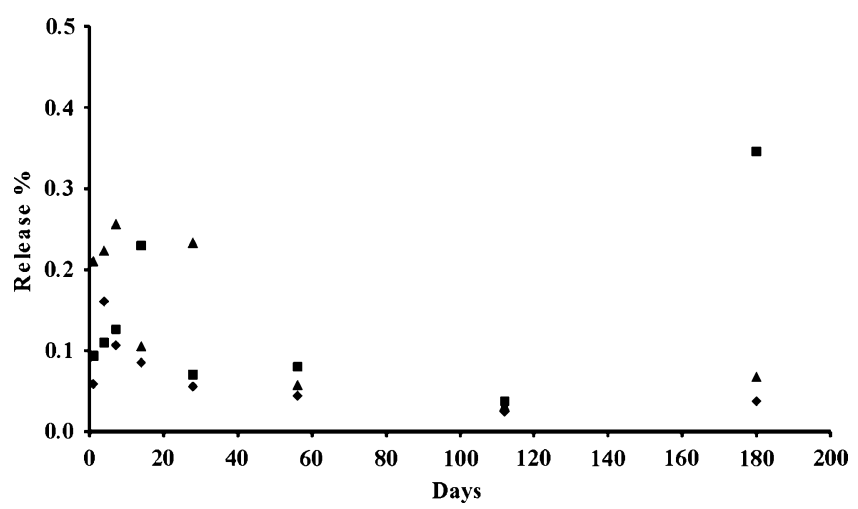

Fig. I Release of holmium from HoAcAcMS (diamonds) and ${ }^{166} \mathrm{HoAcAcMS}$ irradiated for either $3 \mathrm{~h}$ (triangles) or $6 \mathrm{~h}$ (squares) during incubation in phosphate buffer for 6 months. The data are presented as the mean of two measurements. 
(1.5-2.0\% $\mathrm{O}_{2}$ /air (1:1)). For post-administration imaging, the animals were sedated using dexmedetomidine at $50 \mathrm{mg} \mathrm{kg}^{-1}$ and ketamine at $15 \mathrm{mg} \mathrm{kg}^{-1}$. The animals were euthanized by intravenous injection of $600 \mathrm{mg}$ pentobarbital.

\section{Tumor Implantation}

A subxiphoid laparotomy was performed by ventral midline incision, in order to expose the liver lobes. Three tumor pieces were implanted into the left lateral liver lobe with an intravenous catheter (Abbocath-T 16 G, Hospira, Donegal Town, Ireland). After implantation of tumor tissue, the puncture wound in the liver was sealed with tissue glue (Histoacryl, B. Braun, Melsungen, Germany). Thereafter the abdominal muscle layer and skin layers were sutured in separate layers using Vicryl 3.0 (Johnson\&Johnson Intl., StStevens-Woluwe, Belgium).

\section{Dose Preparation}

Neutron irradiation of approximately $60 \mathrm{mg}$ HoAcAcMS for $1 \mathrm{~h}$ resulted in an activity of approximately $600 \mathrm{MBq}$ ${ }^{166}$ HoAcAcMS. The ${ }^{166}$ HoAcAcMS were suspended in $1.2 \mathrm{~mL}$ of sterile water containing $2 \%$ Pluronic ${ }^{\circledR}$ F68 and $10 \%$ ethanol abs. to obtain a final concentration of
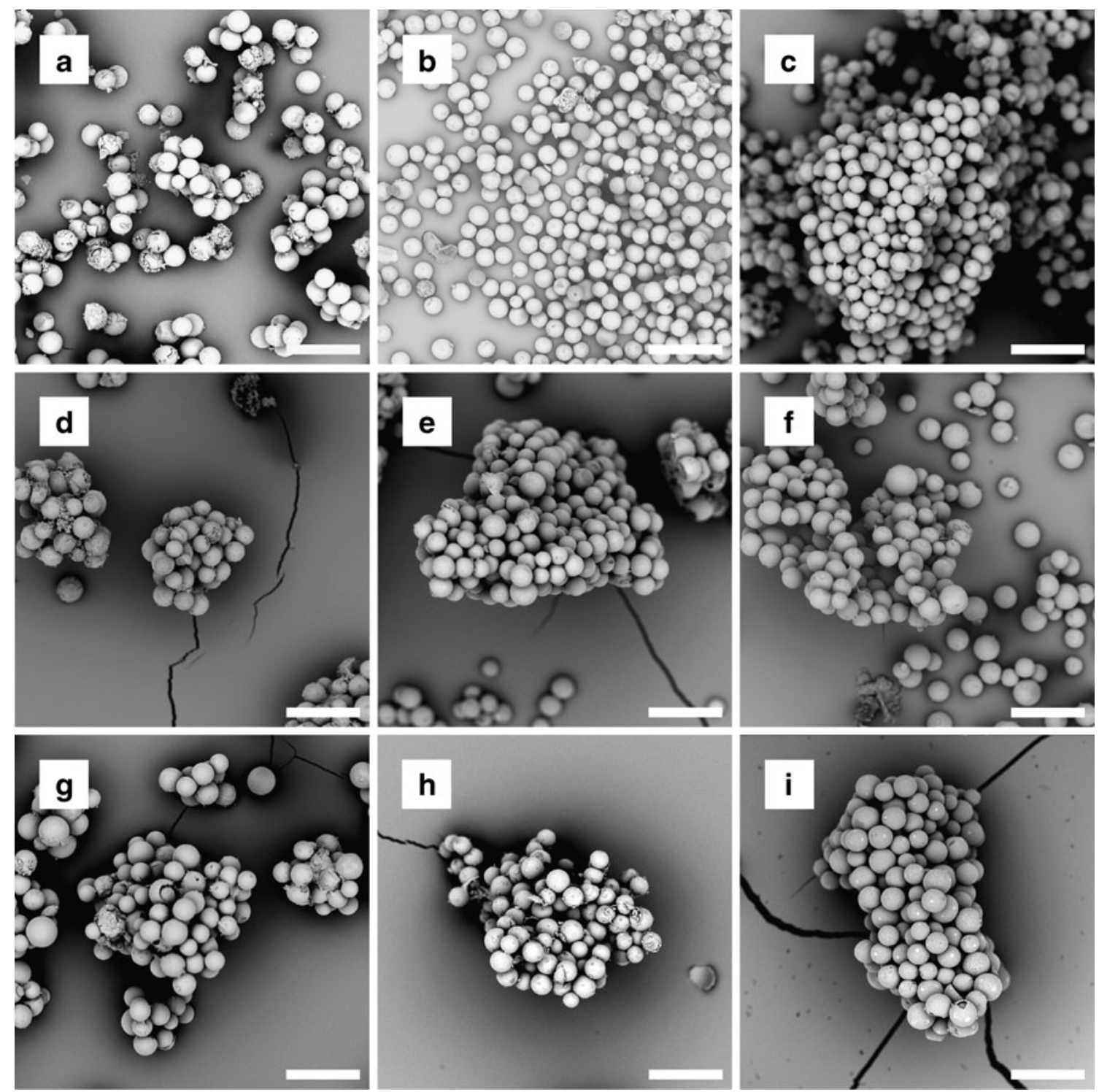

Fig. 2 Scanning electron micrographs of HoAcAcMS and ${ }^{166} \mathrm{HoAcAcMS}$ after incubation for different times in phosphate buffer. (a-c) HoAcAcMS, (a) after I month, (b) after 3 months and (c) after 6 months of incubation. (d-f) ${ }^{166} \mathrm{HoAcAcMS}$ neutron irradiated for $3 \mathrm{~h}$ at a neutron flux of $5 \times 10^{12} \mathrm{n}$ $\mathrm{cm}^{-2} \mathrm{~s}^{-1}(\mathbf{d})$ after I month, (e) after 3 months and $(\mathbf{f})$ after 6 months of incubation. (g-i) ${ }^{166} \mathrm{HoAcAcMS}$ neutron irradiated for $6 \mathrm{~h}$ at a neutron flux of $5 \times$ $10^{12} \mathrm{n} \mathrm{cm}^{-2} \mathrm{~s}^{-1}(\mathbf{g})$ after I month, (h) after 3 months and (i) after 6 months of incubation. The magnification in all images is $1000 \mathrm{x}$, the bar represents $50 \mu \mathrm{m}$. 
Table I Elemental Composition of the HoAcAcMS after Incubation in a 116 mM Phosphate Buffer

\begin{tabular}{|c|c|c|c|c|c|c|c|c|c|c|c|c|}
\hline & \multicolumn{2}{|l|}{ Day $0^{a}$} & \multicolumn{2}{|l|}{ Day I } & \multicolumn{2}{|l|}{ Day 4} & \multicolumn{2}{|l|}{ Day 7} & \multicolumn{2}{|c|}{ Day 30} & \multicolumn{2}{|c|}{ Day 90} \\
\hline & $\%^{b}$ & noc & $\%$ & no & $\%$ & no & $\%$ & no & $\%$ & no & $\%$ & no \\
\hline C & 26.4 & 7.5 & 15.0 & 4.4 & 1.0 & 0.3 & 0.6 & 0.2 & 0.5 & 0.1 & 0.7 & 0.2 \\
\hline $\mathrm{H}$ & 4.0 & 13.5 & 3.5 & 12.0 & 1.5 & 4.9 & 2.2 & 7.5 & 1.5 & 4.5 & 1.6 & 4.6 \\
\hline O & 20.3 & 4.3 & 29.0 & 6.3 & 35.4 & 7.2 & 37.9 & 8.1 & 30.9 & 5.7 & 30.1 & 5.6 \\
\hline $\mathrm{Ho}$ & 48.4 & 1.0 & 47.2 & 1.0 & 50.8 & 1.0 & 48.2 & 1.0 & 55.5 & 1.0 & 55.8 & 1.0 \\
\hline$P$ & 0.5 & 0.05 & 5.2 & 0.6 & 10.7 & I.I & 10.7 & 1.2 & 11.3 & I.1 & 11.0 & 1.0 \\
\hline Composition $^{\mathrm{d}}$ & \multicolumn{2}{|c|}{$\mathrm{Ho}_{2}(\mathrm{AcAc})_{3} * \mathrm{H}_{2} \mathrm{O}$} & \multicolumn{2}{|c|}{ Intermediate } & \multicolumn{2}{|c|}{$\mathrm{HoPO}_{4} * 3 \mathrm{H}_{2} \mathrm{O}$} & \multicolumn{2}{|c|}{$\mathrm{HoPO}_{4} * 3 \mathrm{H}_{2} \mathrm{O}$} & \multicolumn{2}{|c|}{$\mathrm{HoPO}_{4} * 3 \mathrm{H}_{2} \mathrm{O}$} & \multicolumn{2}{|c|}{$\mathrm{HoPO}_{4} * 3 \mathrm{H}_{2} \mathrm{O}$} \\
\hline
\end{tabular}

a data taken from Bult et al. (12)

${ }^{b}$ results from elemental analysis are the mean of two values

c no: the number of atoms, normalized on holmium

${ }^{\mathrm{d}}$ Composition: the chemical composition of the particles

$50 \mathrm{mg} \mathrm{mL} \mathrm{m}^{-1}\left(=500 \mathrm{MBq}{ }^{166} \mathrm{HoAcAcMS}^{-1}\right)$. The microspheres were suspended by gentle agitation and repeatedly drawing them up and down with a syringe. Subsequently, approximately $200 \mu \mathrm{L}(=100 \mathrm{MBq}$ or $10 \mathrm{mg}$ ${ }^{166} \mathrm{HoAcAcMS}$ ) was taken up in $29 \mathrm{G}$ insulin syringes (Becton Dickinson Ultra Fine, Breda, the Netherlands), and the activity was measured using a dose calibrator (VDC-404, Veenstra Instruments, Joure, The Netherlands). As a control, a suspension of non-radioactive microspheres was prepared in a similar concentration of microspheres (50 $\mathrm{mg} \mathrm{mL}^{-1}$ ). Approximately $200 \mu \mathrm{L}$ (or $10 \mathrm{mg}$ ) was taken up in $29 \mathrm{G}$ insulin syringes.

\section{Administration of ${ }^{166} \mathrm{HoAcAcMS}$}

Fourteen days post implantation the tumor reached a size of approximately $2 \mathrm{~cm}^{3}$ and a second subxiphoid laparotomy was performed. Prior to administration of the microspheres, the syringe was agitated vigorously to obtain a homogeneous microsphere suspension. One hundred $\mu \mathrm{l}$ of non-radioactive $(=5 \mathrm{mg})$ or radioactive HoAcAcMS (=50 MBq, which corresponds to $5 \mathrm{mg}$ ) suspension was administered intratumorally. The syringes were measured in a dose calibrator before and after administration, to determine the injected amount of activity. Following the intratumoral administration of ${ }^{166} \mathrm{HoAcAcMS}$, the animals were subjected to planar gamma scintigraphy (Forte, Philips Medical Systems, Best, The Netherlands) and CT imaging (Brilliance 64, Philips Medical Systems, Best, The Netherlands) to confirm the selective deposition of microspheres in the tumor.

\section{Release Profile of the ${ }^{166} \mathrm{HoAcAcMS}$}

The urine and faeces of the animals were collected at the same time each day during the first week after

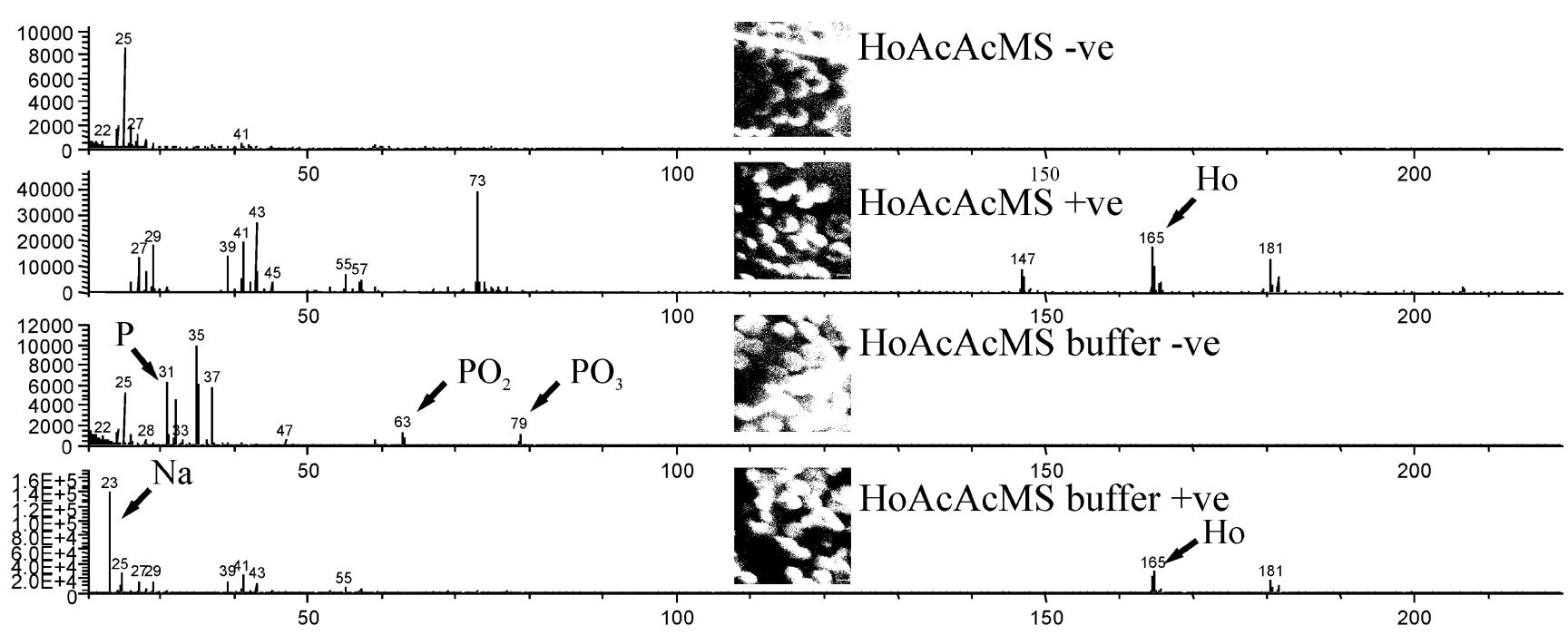

Fig. 3 TOF-SIMS spectra from control HoAcAcMS (HoAcAcMS) and buffer incubated HoAcAcMS (HoAcAcMS buffer). The micrographs show total ion count images in the negative $(-v e)$ and the positive $(+v e)$ secondary ion mode. The peaks of interest are indicated with an arrow. 
administration. Venous blood samples (1 $\mathrm{mL})$ were taken before, just after, 5 days after and 10 days after administration of HoAcAcMS. Blood was centrifuged at $3,000 \mathrm{rpm}$ for $10 \mathrm{~min}$ at $4^{\circ} \mathrm{C}$ and the serum was collected and stored at $-20^{\circ} \mathrm{C}$ for further analysis. The serum levels of alkaline phosphatase (ALP) as an indicator of biliary toxicity, alanine aminotransferase (ALAT), aspartate amino transferase (ASAT) and gamma glutamyltransferase $(\gamma-\mathrm{GT})$ as indicators of hepatocellular toxicity and albumin as indicator for liver function were analysed on a UniCel DxC 800 Clinical System (Beckman Coulter B.V., Woerden, The Netherlands). In addition, the serum holmium levels were measured using inductively coupled plasma-optical emission spectroscopy (ICP OES), as described in section 2.9 .

\section{Histology}

Rabbits were euthanized 4 weeks after administration of HoAcAcMS. After termination, the lungs, heart, stomach, liver, kidneys, and a femur were excised and fixed in a $4 \%$ formalin solution. The tumor bearing liver was dissected and embedded in paraffin. After haematoxylin-eosin staining the liver and tumor tissue was histologically evaluated, to verify the presence of microspheres in the tumor and liver.

\section{Determination of Holmium Concentration}

The holmium concentration in buffer, serum, urine, faeces and bone samples was determined using ICP OES. Buffer samples were prepared by diluting $100 \mu \mathrm{L}$ of supernatant to $5 \mathrm{~mL}$ nitric acid $(5 \% w / v)$. Approximately $1 \mathrm{~g}$ of urine or faeces sample was destructed overnight using $5 \mathrm{~mL}$ nitric acid (30\%). After overnight destruction the samples were centrifuged at 4,000 g and $1 \mathrm{~mL}$ of supernatant was diluted to $5 \mathrm{ml}$ with nitric acid $(5 \% w / v)$. The bone was separated from the marrow of the femur samples. Approximately $500 \mathrm{mg}$ bone sample was weighed accurately, and was destructed in $4 \mathrm{~mL}$ aqua regia (one volume of nitric acid $(65 \%$ w/w) mixed with three volumes hydrochloric acid $(36 \%$ w/w) ) under heating to $100^{\circ} \mathrm{C}$. After evaporation to dryness, the residue was dissolved in $5 \mathrm{~mL}$ nitric acid $(5 \% w / v)$. All samples were measured at three different wavelengths $(339.898 \mathrm{~nm}, 345.600 \mathrm{~nm}$ and $347.426 \mathrm{~nm}$ respectively) by ICP-OES, using an Optima 4300 (PerkinElmer, Norwalk, USA). Analytical calibration curves from the holmium ICP standard solution were used to assess the precision and accuracy of the measurements.
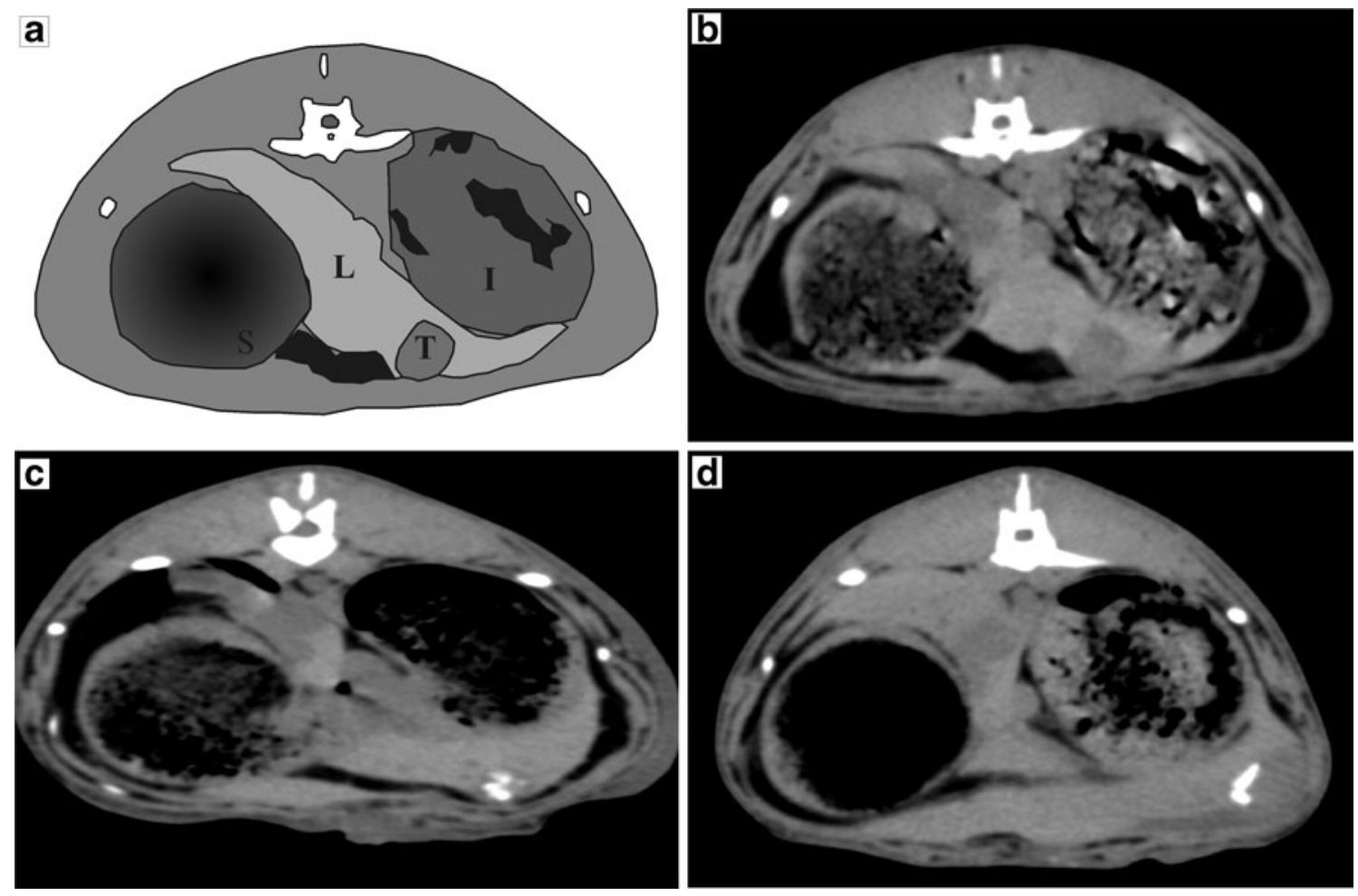

Fig. 4 (a) Schematic outline of rabbit anatomy on $\mathrm{X}$-ray $\mathrm{CT}$ image ( $\mathrm{L}=$ liver, $\mathrm{T}=$ tumor, $\mathrm{S}=$ stomach, $\mathrm{I}=$ intestine). (b) $\mathrm{X}$-ray $\mathrm{CT}$ image of rabbit before intratumoral administration of ${ }^{166} \mathrm{HoAcAcMS}$ showing the tumor, (c) X-ray CT image of rabbit after intratumoral administration of ${ }^{166} \mathrm{HoAcAcMS}$ showing the selective deposition in the tumor as white artifacts, (d) X-ray CT image 4 weeks after administration, before termination, the white area in the tumor is still present as a cluster, although the shape has changed. 


\section{RESULTS AND DISCUSSION}

Microsphere characteristics of the HoAcAcMS used in these experiments were in accordance with previous work (12). The microspheres had a holmium load of $45 \pm$ $1 \%$, and a size of $15 \mu \mathrm{m}(97 \%$ of the microspheres between 10 and $20 \mu \mathrm{m}$ ) after sieving. As previously observed, no differences in size distribution were observed before and after neutron irradiation, irrespective of irradiation time (12).

The in vitro release profile of holmium from the microspheres incubated in phosphate buffer is shown in Fig. 1. As can be observed, the release of holmium was below $0.5 \%$ after 6 months. This is comparable to the holmium release $(0.7 \pm 0.2 \%)$ reported for holmium loaded poly(L-lactic acid) microspheres (HoPLLAMS) in the same buffer (16). The HoPLLAMS are considered radiochemically stable and are currently under clinical investigation in a Phase I study for treatment of liver malignancies (20).

Electron microscopic inspection of the HoAcAcMS after incubation in phosphate buffer showed clusters of microspheres amidst buffer. Since the surface charge of the HoAcAcMS is expected to be near neutral (21), the microspheres aggregate upon settling due to gravitational forces. The phosphate buffer filled the inter-microsphere spaces which turned into buffer salts upon drying, thereby encapsulating the microspheres. The microspheres remained intact, irrespective of the neutron irradiation time and incubation time (Fig. 2). The surface of the microspheres was still smooth after 26 weeks in buffer. This finding is in contradistinction to neutron irradiated HoPLLAMS incubated in a similar buffer (16) which showed a rough surface after 12 weeks of incubation and started to disintegrate after 24 weeks incubation. This disintegration was attributed to hydrolysis of the poly(L-lactic acid), leading to the formation of holmium lactate (16).

The HoAcAcMS were subjected to elemental analysis to determine their composition after incubation in phosphate buffer (Table I). Interestingly, a quantitative exchange of acetylacetonate by phosphate was observed within 4 days of incubation. To confirm the exchange of acetylacetonate by phosphate, IR analysis was performed. The characteristic
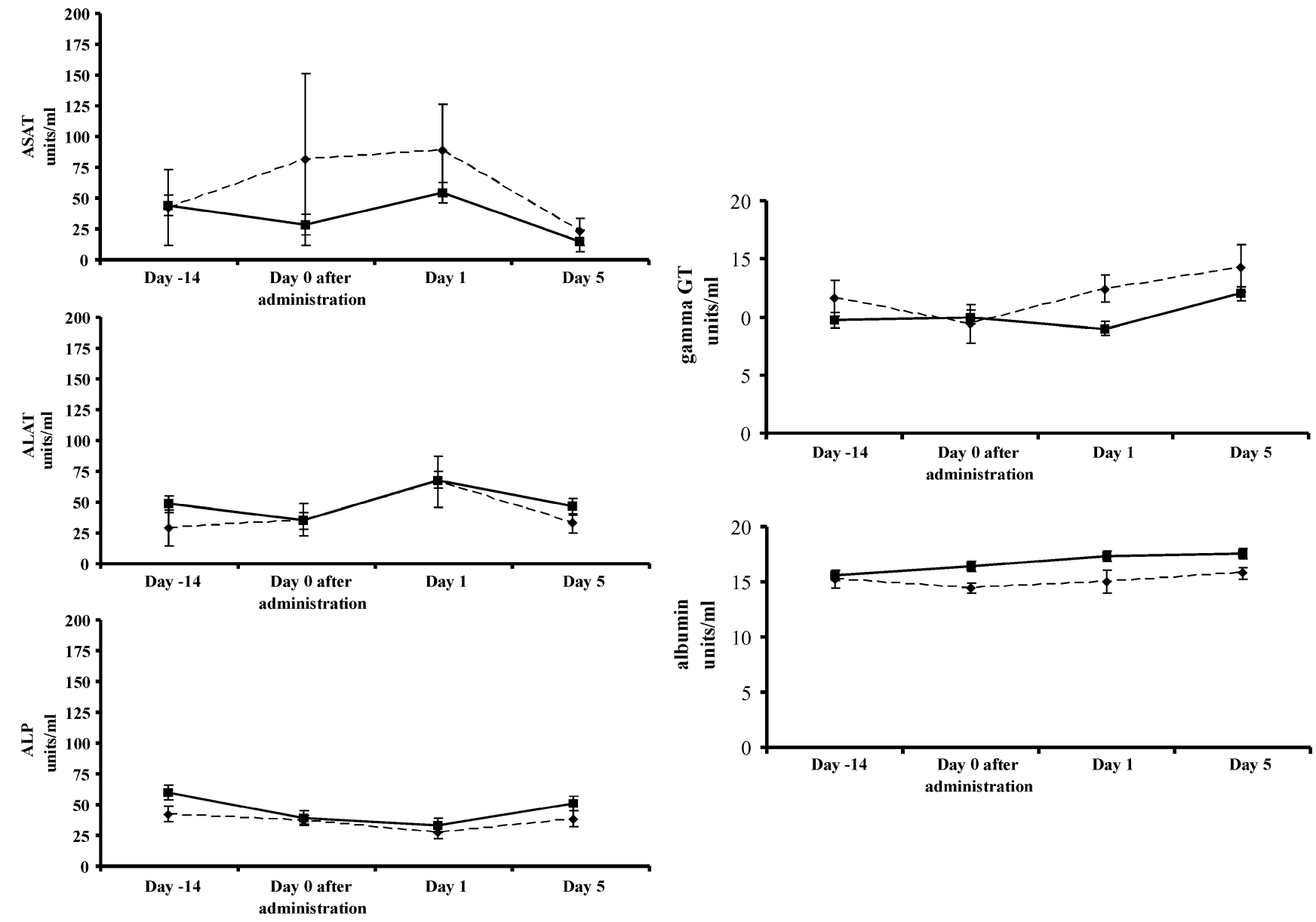

Fig. 5 Serum enzyme levels (ASAT, ALAT, Y-GT, ALP and albumin) of rabbits that received non-radioactive HoAcAcMS (solid line) and radioactive ${ }^{166} \mathrm{HoAcAcMS}$ (dotted line) in time. Bars represent SD. 
peaks of holmium acetylacetonate around $1,518 \mathrm{~cm}^{-1}$ are present in the samples before and after 1 day of incubation in buffer. The intensity of this peak reduces in time and after 1 month it could not be observed anymore. Interestingly, after 4 days a broad peak around $1,100 \mathrm{~cm}^{-1}$ appeared, which can be attributed to stretching bands of phosphate groups (22).

TOF-SIMS analysis of HoAcAcMS before and after incubation in buffer showed spherical particles in total ion count mode (Fig. 3). The resulting mass spectrum showed differences between HoAcAcMS incubated in phosphate buffer and HoAcAcMS before incubation in buffer. The negative ions observed in the HoAcAcMS incubated in buffer were oxygen, chlorine, and phosphorous compounds $\left(m / z\right.$ 31: $\mathrm{P}^{-} ; m / z$ 63: $\left.\mathrm{PO}_{2}{ }^{-} ; m / z 79 \mathrm{PO}_{3}{ }^{-}\right)$, which were absent in the spectrum of the non incubated microspheres (Fig. 3). All negative ions were distributed evenly through the microspheres, indicating a complete exchange of acetylacetonate by phosphate in the microspheres. Holmium $(\mathrm{m} / \mathrm{z} 165)$, and holmium-oxygen $(\mathrm{m} / \mathrm{z} 181)$ was present in both the incubated and non incubated samples. The incubated samples also showed a large peak of sodium $(\mathrm{m} / z 23)$ from the buffer salts, which was only present at the particle surface. The HoAcAcMS before incubation in phosphate buffer show additional peaks in the positive secondary ion mode at $m / z 74$ and $m / z 147$, which can be attributed to trimethylsilylgroups from polydimethylsiloxane (23) that is present on the surface of the carbon sticker.

The results of IR analysis and TOF-SIMS confirm elemental analysis data that phosphate has replaced acetylacetonate after suspension in buffer. This in turn explains the limited release of holmium from the microspheres, since rare earth metal phosphates are practically insoluble in aqueous media; the solubility product of $\mathrm{HoPO}_{4}$ in water is lower than $10^{-25} \mathrm{M}(24)$. The exchange of acetylacetonate by phosphate, without changing the surface morphology, is a so called chimie douce reaction (25). Chimie douce reactions are topotactic meaning that the products retain the precursor geometry, and usually take place under mild conditions. Beta diketones, like acetylacetonate, are prone to these types of reactions $(26,27)$.

The in vivo stability study was carried out to determine the in vivo implications of the results obtained in the in vitro experiment. Radioactive and cold HoAcAcMS were administered intratumorally to VX2 carcinoma-bearing rabbits. All animals recovered from anaesthesia, and the animals received $40 \pm 10 \mathrm{MBq}{ }^{166} \mathrm{HoAcAcMS}$, corresponding to $4 \pm 1 \mathrm{mg}$ microspheres intratumorally. Approximately $80 \%$ of the intended dose was administered, which was attributed to the premature settling of the microspheres in the syringes. Nuclear imaging and CT imaging showed a selective administration of microspheres in the tumor (Fig. 4). One animal showed uptake of activity in the lungs (approximately $5 \%$ of the injected dose) apart from uptake in the tumor, due to the inadvertent delivery of ${ }^{166} \mathrm{HoAcAcMS}$ in a blood vessel surrounding the tumor artery. This animal however, completed the experiment in good health. The inadvertent delivery of activity can be avoided in humans by administering the microspheres under ultrasound guidance, making it easier to distinguish tumor tissue from blood vessels and liver tissue (6).

The excretion of holmium after intratumoral administration of HoAcAcMS to the blood, urine and the faeces was below the detection limit in all samples $(0.1 \mathrm{ppm}$ for Ho). Suzuki and co-workers found that release of free holmium $\left(\mathrm{Ho}^{3+}\right)$ to the urine and faeces occurred rapidly after local intrahepatic administration of the in-situ gel forming complex holmium-166-chitosan (28). Therefore it can be concluded that $\mathrm{Ho}^{3+}$ was not released from the HoAcAcMS, and that the microspheres retained their integrity as confirmed by histology.
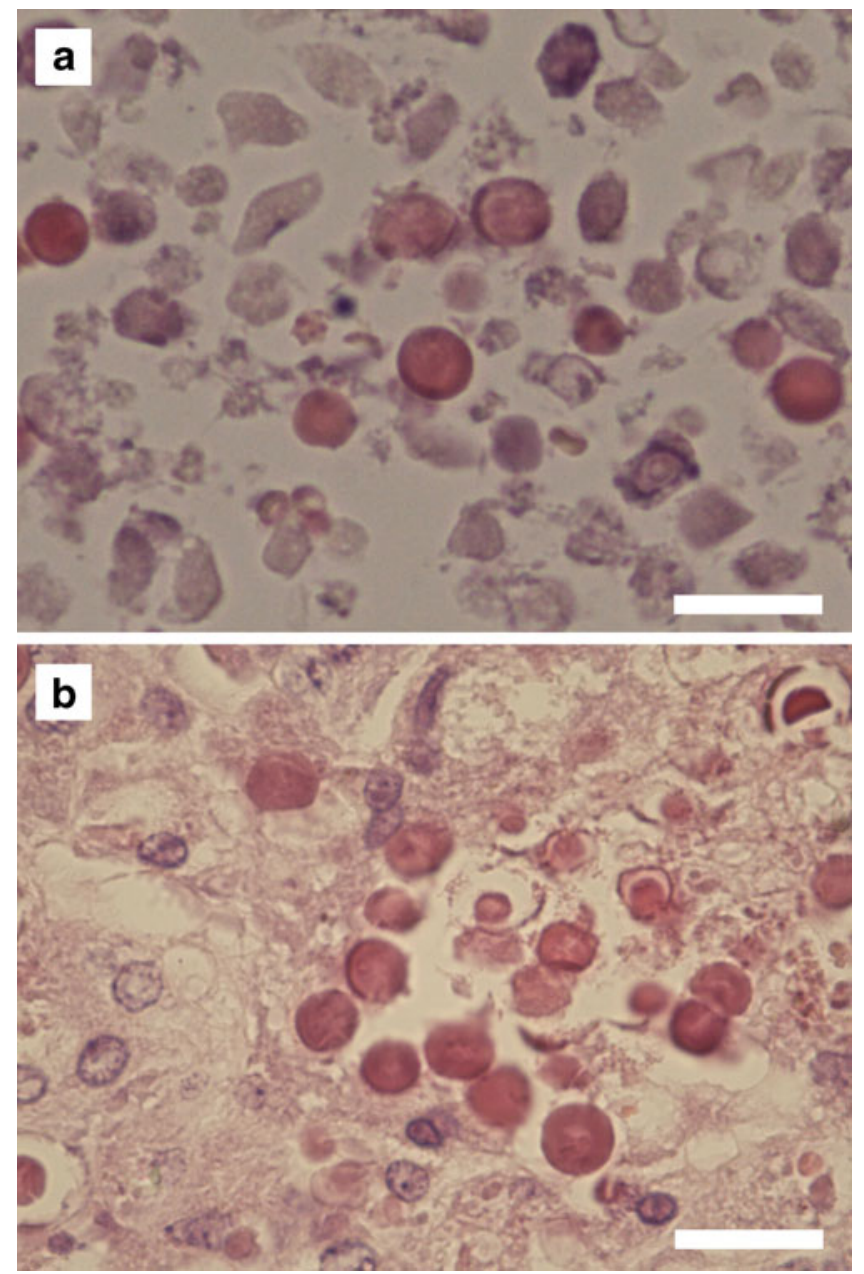

Fig. 6 Light micrographs at 400x magnification of a H\&E stained section of tumor tissue showing microspheres amidst necrotic tissue. (a) non-radioactive HoAcAcMS. (b) ${ }^{166} \mathrm{HoAcAcMS}$. The microspheres in red are clustered amidst necrotic tissue. The bar represents $20 \mu \mathrm{m}$. 
Although the results from the in vitro and the in vivo stability study show a minimal to no release of holmium from the HoAcAcMS, the in vivo data cannot be related to the chimie douce reaction found in vitro. The phosphate concentration $(116 \mathrm{mM})$ used for the in vitro experiment is substantially higher than the phosphate concentration in human serum (around $1.5 \mathrm{mM}(29))$. The high phosphate concentration in vitro was required to keep the $\mathrm{pH}$ stable throughout the experiment, which, however, might accelerate the exchange of acetylacetonate by phosphate. The exchange of acetylacetonate by phosphate could not be established in vivo since paraffin interfered with the TOF-SIMS measurements, nonetheless, the presence of intact microspheres and the absence of holmium in urine, faeces and blood show that the HoAcAcMS are stable in vivo. The identification of the chemical structure of the HoAcAcMS after intratumoral administration requires further research.

A transient rise in ASAT was observed after the administration of the radioactive microspheres, which can be attributed to the subxiphoid manipulation of liver tissue, and radiation effects of the ${ }^{166} \mathrm{HoAcAcMS}$. No other elevations from baseline levels or differences in serum enzyme levels were found between the radioactive and non-radioactive group (see Fig. 5). ASAT and ALAT are markers for short term liver damage, whereas gamma GT and Alkaline Phosphatase are a measure for long-term (chronic) liver damage. Albumin levels are a marker for the liver function, since the liver is the main site for albumin production (30). The transient rise in ASAT was previously observed after transcatheter radioembolization with both ${ }^{90} \mathrm{Y}$ microspheres in human liver cancer patients (31) and ${ }^{166}$ HoPLLAMS in healthy pigs (30). This transient rise was attributed to the manipulation of liver tissue and radiation effects of the microspheres (30,31). No changes in serum enzyme levels or albumin levels were observed in the present study, an indication that the liver function was neither impaired by the tumor, nor intratumoral administration of either HoAcAcMS or ${ }^{166} \mathrm{HoAcAcMS}$.

Histological evaluation of liver sections showed intact microspheres amidst necrotic tissue both for HoAcAcMS and ${ }^{166} \mathrm{HoAcAcMS}$ (Fig. 6), which is in agreement with the results from the in vitro stability study showing intact HoAcAcMS after 6 months incubation in buffer (Fig. 2). Both the non-radioactive HoAcAcMS and the ${ }^{166} \mathrm{HoAcAcMS}$ are surrounded by necrotic tissue. The VX2 tumor is a rapid-growing tumor, with a viable rim and a necrotic core. Therefore, the HoAcAcMS are surrounded by necrotic tissue (Fig. 6a). Radiation damage from the ${ }^{166} \mathrm{HoAcAcMS}$ resulted in the necrotic tissue surrounding the cluster of microspheres (Fig. 6b).

Possible release of holmium from the HoAcAcMS was determined by measuring the holmium content in bone.
Holmium is a bone seeking element, and it has been shown that within 4 days after intravenous administration of holmium nitrate, approximately $55 \%$ of the injected dose accumulates in bone (32). Therefore, if holmium $\left(\mathrm{Ho}^{3+}\right)$ would be released from the HoAcAcMS in vivo, the holmium levels in bone would be elevated. In accordance with the holmium levels in urine and faeces, the holmium levels in all bone samples were below the detection limit and it can be concluded that no release of holmium from the HoAcAcMS has occurred.

\section{CONCLUSION}

This paper demonstrates the stability of HoAcAcMS, both in vitro and in vivo. The in vitro release was approximately $0.5 \%$ after 6 months of incubation in buffer. The microspheres remained spherical, and a $\mathrm{HoPO}_{4}$ complex was formed while the surface morphology was retained. No release of holmium was observed after the intratumoral injection of HoAcAcMS in VX2 tumor-bearing rabbits, and the microspheres remained intact in tumor tissue for 1 month. The results confirm the potential of these microspheres as a novel intratumoral radioablation device.

\section{ACKNOWLEDGMENTS \& DISCLOSURES}

Financial support by the Dutch Technology Foundation STW, under grant 06069 is gratefully acknowledged. Dr. G.C. Krijger and ms. M.J.J. Koster-Ammerlaan are acknowledged for performing the neutron irradiations. Ms. H.M. de Bruin, Mr. N.J.M. Attevelt and Mr. H.W.G. Vosmeer are gratefully acknowledged for biotechnical assistance. The authors would like to thank prof. dr. K.P. de Jong for valuable discussions. Dr. W.H. Müller and Mr. C.J.M.M. Schneijdenberg are acknowledged for their assistance with the SEM measurements.

Open Access This article is distributed under the terms of the Creative Commons Attribution Noncommercial License which permits any noncommercial use, distribution, and reproduction in any medium, provided the original author(s) and source are credited.

\section{REFERENCES}

1. Jemal A, Siegel R, Ward E, Hao Y, Xu J, Thun MJ. Cancer statistics, 2009. CA Cancer J Clin. 2009;59(4):225-49.

2. Parkin DM, Bray F, Ferlay J, Pisani P. Global cancer statistics, 2002. CA Cancer J Clin. 2005;55(2):74-108.

3. Kennedy JE. High-intensity focused ultrasound in the treatment of solid tumours. Nat Rev Cancer. 2005;5(4):321-7. 
4. McGahan JP, Browning PD, Brock JM, Tesluk H. Hepatic ablation using radiofrequency electrocautery. Invest Radiol. 1990;25(3):267-70.

5. Ter Haar G, Sinnett D, Rivens I. High intensity focused ultrasound-a surgical technique for the treatment of discrete liver tumours. Phys Med Biol. 1989;34(11):1743-50.

6. Tian JH, Xu BX, Zhang JM, Dong BW, Liang P, Wang XD. Ultrasound-guided internal radiotherapy using yttrium-90-glass microspheres for liver malignancies. J Nucl Med. 1996;37(6):958-63.

7. Liapi E, Geschwind JF. Transcatheter and ablative therapeutic approaches for solid malignancies. J Clin Oncol. 2007;25(8):978-86.

8. Vente MA, Wondergem M, van der Tweel I, van den Bosch MA, Zonnenberg BA, Lam MG, et al. Yttrium-90 microsphere radioembolization for the treatment of liver malignancies: a structured meta-analysis. Eur Radiol. 2009;19:951-9.

9. Lewandowski RJ, Geschwind JF, Liapi E, Salem R. Transcatheter intraarterial therapies: rationale and overview. Radiology. 2011;259(3):641-57.

10. Kim JK, Han KH, Lee JT, Paik YH, Ahn SH, Lee JD, et al. Long-term clinical outcome of phase IIb clinical trial of percutaneous injection with holmium-166/chitosan complex (Milican) for the treatment of small hepatocellular carcinoma. Clin Cancer Res. 2006;12(2):543-8.

11. Seevinck PR, Seppenwoolde JH, de Wit TC, Nijsen JF, Beekman FJ, van het Schip $\mathrm{AD}$, et al. Factors affecting the sensitivity and detection limits of MRI, CT, and SPECT for multimodal diagnostic and therapeutic agents. Anticancer Agents Med Chem. 2007:7:317-34.

12. Bult W, Seevinck PR, Krijger GC, Visser T, Kroon-Batenburg LM, Bakker CJ, et al. Microspheres with ultrahigh holmium content for radioablation of malignancies. Pharm Res. 2009;26(6):1371-8.

13. Bult W, Kroeze SGC, Elschot M, Seevinck PR, Beekman FJ, Luijten PR, Hennink WE, van het Schip AD, Bosch JLHR, Nijsen JFW, Jans JJM. Intratumoral administration of holmium-166 acetylacetonate microspheres as a novel minimally-invasive treatment for small kidney tumors. Thesis Utrecht University, 2010. p. 89-105.

14. Bult W, Vente MAD, Vandermeulen E, Gielen I, Seevinck PR, Saunders J, van het Schip AD, Bakker CJG, Krijger GC, Peremans K, Nijsen JFW. Interstitial microbrachytherapy using holmium-166 acetylacetonate microspheres: a pilot study in feline liver cancer patients. Brachytherapy, accepted for publication

15. Vente MA, Nijsen JF, de Roos R, van Steenbergen MJ, Kaaijk GN, Koster-Ammerlaan MJ, et al. Neutron activation of holmium poly(L-lactic acid) microspheres for hepatic arterial radio-embolization: a validation study. Biomed Microdevices. 2009;1 1(4):763-72.

16. Zielhuis SW, Nijsen JFW, Krijger GC, van het Schip AD, Hennink WE. Holmium-loaded poly(L-lactic acid) microspheres: In vitro degradation study. Biomacromolecules. 2006;7(7):2217-23.

17. Chughtai K, Heeren RM. Mass spectrometric imaging for biomedical tissue analysis. Chem Rev. 2010;110(5):3237-77.
18. van Es RJ, Franssen O, Dullens HF, Bernsen MR, Bosman F, Hennink WE, et al. The VX2 carcinoma in the rabbit auricle as an experimental model for intra-arterial embolization of head and neck squamous cell carcinoma with dextran microspheres. Lab Anim. 1999;33(2):175-84.

19. Nijsen JFW. Radioactive holmium poly(L-lactic acid) microspheres for treatment of hepatic malignancies: efficacy in rabbits. Thesis Utrecht University, 2001. p. 109-122.

20. Smits ML, Nijsen JF, van den Bosch MA, Lam MG, Vente MA, Huijbregts JE, et al. Holmium-166 radioembolization for the treatment of patients with liver metastases: design of the phase I HEPAR trial. J Exp Clin Cancer Res. 2010;29:70.

21. Bult W, Varkevisser R, Soulimani F, Seevinck PR, de Leeuw H, Bakker CJ, et al. Holmium nanoparticles: preparation and in vitro characterization of a new device for radioablation of solid malignancies. Pharm Res. 2010;27(10):2205-12.

22. Lide DR, ed. CRC handbook of chemistry and physics, 89th Edition(Internet Version 2009). Boca Raton, FL: CRC Press/Taylor and Francis.

23. Dong X, Gusev A, Hercules DM. Characterization of polysiloxanes with different functional groups by time-of-flight secondary ion mass spectrometry. J Am Soc Mass Spectrom. 1998;9(4):292-8.

24. Kijkowska R, LeGeros RZ. Preparation and properties of lanthanide phosphates. Key Eng Mater. 2005;246/248(1/2): 79-82.

25. Rouxel J, Tournoux M. Chimie douce with solid precursors, past and present. Solid State Ionics. 1996;84(3-4):141-9.

26. Lu C, Ding ZF, Lipson RH. A new chimie douce approach to crystalline vanadium pentoxide nanobelts. J Mater Chem. 2009;19(36):6512-5.

27. Harlan CJ, Kareiva A, MacQueen DB, Cook R, Barron AR. Yttrium-doped alumoxanes: A chimie douce route to Y3Al5O12 (YAG) and Y4Al2O9 (YAM). Adv Mater. 1997;9(1):68-71.

28. Suzuki YS, Momose Y, Higashi N, Shigematsu A, Park KB, Kim YM, et al. Biodistribution and kinetics of holmium-166-chitosan complex (DW-166HC) in rats and mice. J Nucl Med. 1998;39 (12):2161-6.

29. Sinton TJ, Cowley DM, Bryant SJ. Reference intervals for calcium, phosphate, and alkaline phosphatase as derived on the basis of multichannel-analyzer profiles. Clin Chem. 1986;32(1 Pt 1):76-9.

30. Vente MAD, Nijsen JFW, de Wit TC, Seppenwoolde JH, Krijger $\mathrm{GC}$, Seevinck PR, et al. Clinical effects of transcatheter hepatic arterial embolization with holmium-166 poly(L: -lactic acid) microspheres in healthy pigs. Eur J Nucl Med Mol Imaging. 2008;35(7):1259-71.

31. Salem R, Thurston KG, Carr BI, Goin JE, Geschwind JF. Yttrium-90 microspheres: radiation therapy for unresectable liver cancer. J Vasc Interv Radiol. 2002;13(9 Pt 2):S223-9.

32. Durbin PW. Metabolic characteristics within a chemical family. Health Phys. 1960;2:225-38. 